\title{
The Women's Language Features in Moana Movie
}

\author{
Yosep Sanjaya \\ English Department Faculty of Arts - Udayana University \\ [yosefsanjayafsb@gmail.com]
}

\begin{abstract}
The title of this paper is The Women's Language Features in Moana Movie. This study aimed at identifying the women's language features are applied by women and finding the context of the situation that influenced women's language. The women's language is analyzed based on the theory of sociolinguistics which is proposed by Lakoff (1975). The second theory applied to analyze the context of the situation is proposed by Halliday and Hasan (1989) who divides into three concepts: field of discourse, tenor of discourse, and mode of discourse. The data of this study was taken from a movie entitled Moana. The movie was chosen as the data source in this study because it contained many women conversations either formal or informal situation. The analysis comes to a conclusion. There were seven features of women's language found in the movie entitled Moana, and the context of situation that influenced women language.
\end{abstract}

Key words: women's language, women's language features, the context of the situation

\section{Abstrak}

Judul dari tulisan ini adalah The Women's Language Features in Moana Movie. Penelitian ini bertujuan untuk mengidentifikasi bahasa perempuan. Bahasa perempuan sendiri dianalisis berdasarkan teori yang berasal dari teori sosiolinguistik yang dikemukakan oleh Lakoff (1975) dan teori ke dua yang di adopsi untuk menganalisis context of the situation di kemukakan oleh Halliday dan Hasan (1989) yang menjabarkannya menjadi tiga konsep yaitu: Field of discourse, Tenor of discourse, dan Mode of discourse. Data untuk penelitian ini diambil dari sebuah film yang berjudul Moana. Film ini dipilih sebagai sumber data dalam penelitian ini dikarenakan film ini mengandung banyak percakapan yang melibatkan wanita, baik dalam situasi formal maupun informal. Analisis ini sampai kepada kesimpulan, dimana terdapat tujuh women's language features di dalam film berjudul Moana, dan context of the situation yang mempengaruhi bahasa wanita.

Kata kunci: bahasa perempuan. fitur bahasa perempuan, konteks situatsi

\section{Background of the Study}

The major thing that distinguishes human being from other creatures is basically the way people communicate with others by using language. Hornby (2005) said that woman is an adult female human with female sex. Observation of the function of woman language features is a crucial thing in woman life. We are as the social creatures need to interact with each other. We need a language to express our feeling, thought, and ideas. Language is a human product which is used to share our ideas, thought and feeling. There will be different features and functions of language based on the writer or speaker and reader or hearer. The situation and 
condition also have the role in influencing the features and functions of language. Moreover, the language especially the speech is different in form and address term, depending on the user. It is found that male and female often use different linguistic forms and address terms in speaking English even in the same speech community. The women language itself often talks around the issue about gender. According to Lakoff (1975) women's language is the "language of powerless"; a reflection of their subordinate place in relation to men. She identifies several language features which are considered unique to the speech of women as opposed to that of men. She also explains a constitutive relationship between women and the language she describes: women are systematically taught to speak with specific language features, and those language features are associated with a lack of power. In this globalization era, the use women's language features can be found in the movie. Movie is one of great literatures. Today, we can easily find movies which include the women's language features. In this study, Moana's movie in which actresses are women was taken as the data source. It is used as the data source as it can be easily checked how the actresses apply the women's language features. It also can be influenced by the situation of the conversation

\section{Problems of the Study}

a. What types of women's language features are found in the movie entitled Moana?

b. How does the context of situation influence women's language?

\section{Aims of the Study}

a. To classify and describe the types of women's language features found in the Moana's movie. b. To identify the context of situation that influences the women's language in the Moana's movie.

\section{Research Method}

The research method in this study consists of data source, method and technique of collecting method and technique of analyzing the data, and method and technique of presenting data.

\subsection{Data Source}

The data of women's language features were taken from the movie entitled "Moana". The movie was produced by Walt Disney Animation Studios; it is the $56^{\text {th }}$ Disney animated future film directed by Ron Clements and John Johnson, co-directed by Don Hall and Chris William, written by Pamela Ribon and starred by Dwayne Johnson. Pamela Ribon is a woman; she used women's language in the movie since she knows that the main character is a women.

\subsection{Method and Technique of Collecting Data}

The method and technique of collecting data in this study is the documentary method. The data were collected through documentary method by conducting library research and direct observation of the movie. First, watching intensively and note taking the women's language such as the words, phrases, or sentences, which occurred in the conversation used by women in the movie Moana. Then reading, and classifying the women language based on the theory proposed by Lakoff (1975).

\subsection{Method and Technique of Analyzing Data \\ The descriptive qualitative} method was used to analyse various types of the women's language features; the data were selected to a certain number for the types of women's language features Second, the selected data were described deeply in order to identify the forms, then 
the women's language futures were identified.

\section{Analysis}

\subsection{The Analysis of Language Features Used by Women}

\subsubsection{Lexical Hedges or Fillers}

Women's speech in general contains the words that convey the sense that the speaker is uncertain about what she is saying or cannot exactly state the accuracy of the statement:

Data 1:

Maui : Look what I did was ... wrong. I have no excuse.

Moana : You know, it'd rude to refuse a gift from a goddess

In the above data, the conversation occurred between Moana and Maui when Maui got back his hook from goddess. In her utterance, Moana used the hedge you know since she saw that Maui just felt awkward when he was regretting what he did before.

\subsubsection{Tag Questions}

The number of tag questions used by women and men is not significantly different important than what really is. Some examples are as follows:

Data 5:

Tomeatoa : You're a funny-looking little thing, aren't you

Moana : Don't! That's my gramma's

Tamatoa used tag aren't you since he was pretty certain that his statement would be accepted.

\subsubsection{Rising or Question Intonation on Declarative}

There is a peculiar sentence intonation-pattern, found in English as far as I know only among women, which has the form of declarative answer to a question, and is used as such, but has the rising inflection typical of a yes-no question as well as being especially hesitant.

\section{Data 7:}

Moana : Dad? What are you doing? Chief Tui: I should've burned those boats a long time ago.

In Moana's utterance she used rising intonation on declarative to get the confirmation from the addresse.

\subsection{Analysis of the Context of Situation that influences the Women's Language.}

The theory used to analyze the meaning of figurative language in the movie script "The Study In Pink" is proposed by Leech (1974). There are three types of meaning in figurative expression used in this movie script. They are social meaning, affective meaning, and reflected meaning.

\subsubsection{Analysis of the Context of Situation from data 2 (lexical hedges or fillers)}

Data 2:

Maui : You're measuring the star, not giving the sky a high five Moana: It's cold, wait. It's getting warmer. Aah! That is disgusting

\section{a. Field}

It can be seen that the data 2 is about giving information. The women's 
language features that Moana used in the data 2 is a lexical hedge or filler (wait)

\section{b. Tenor}

It can be seen that Moana and Maui are just friends, not too close friends, by using you to Maui in the data. The women's language feature used by Moana is a lexical hedge or filler (wait)

c. Mode

It can be seen that the type of language used in data 2 is conversation. It is called conversation because it involves more than one people talking together

\section{Conclusion}

There were seven features of women's language found in the movie Moana such as: lexical hedges of fillers (you know, wait, so, well), tag questions (aren't you?, did iy?), rising intonation on declaratives (dad, heiheihei, see), intensifier (so, just), hypercorrect grammar (I didn't meant, will, I've got), super polite form (our strength lie beneath the surface. Far beneath in some case, there is nowhere you could go that I won't be with you), and emphatic stress (nice). Most of the women's language features proposed by Lakoff (1975) were proven in the movie Moana. The analysis of how does the context of the situation influenced women's language is divided into Field of Discourse (what?), Tenor of Discourse: (who), Mode of Discourse (what type of language used).

\section{Reference}

Halliday, and Hasan, R. 1989. Language, Context, and Text: Aspects of Language In A Social - Semiotic Perspective.

Oxford: Oxford University Press.
Hornby, AS. 2005. Oxford Advanced Learner's Dictionary $7^{\text {th }}$ Edition. Oxford: Oxford University Press

Lakoff, R. 1975. Language and Women's Place. New York: Harper \& Row 